Terakreditasi: SK No.: 60/E/KPT/2016

Website : http://ejournal.undip.ac.id/index.php/reaktor/

Reaktor, Vol. 17 No. 2, Juni Tahun 2017, Hal. 81-88

\title{
Kinetika Detoksifikasi Umbi Gadung (Dioscorea hispida dennst.) Secara Fermentasi dengan Kapang Mucor racemosus
}

\author{
Marissa Widiyanti ${ }^{1,2)}$ dan Andri Cahyo Kumoro ${ }^{1, *)}$ \\ ${ }^{1)}$ Departemen Teknik Kimia, Fakultas Teknik, Universitas Diponegoro \\ J1. Prof. Soedarto, SH Tembalang Semarang 50275 \\ Telp./Fax. (024)7460058/(024)76480675 \\ ${ }^{2)}$ Program Studi Magister Teknik Kimia, Departemen Teknik Kimia, Fakultas Teknik, Universitas Diponegoro \\ Jl. Prof. Soedarto, SH Tembalang Semarang 50275 \\ Telp./Fax. (024)7460058/(024)76480675 \\ *)Penulis korespondensi:andrewkomoro@che.undip.ac.id
}

\begin{abstract}
THE KINETICS OF GADUNG (Dioscorea hispida dennst.) TUBER DETOXIFICATION VIA FUNGAL FERMENTATION USING Mucor racemosus. Bitter yam (Dioscorea hispida Dennst.) is one of carbohydrate sources used as staple food commonly found in Indonesian dry-land. However, this tuber has been underutilized due to the presence of an antinutrition compound, namely cyanogenic glucosides. Removal of cyanides from foodstuffs can be done either by physical, chemical or biological methods. In this study, the effect of time on the detoxification of gadung tuber chips from cyanides via fermentation using Mucor racemosus and its kinetics were investigated. Gadung chip samples were withdrawn from the fermentation system at every 24 hours interval for biomass and cyanides contents analysis. It was clear that the cyanides content decreased as the fermentation went by. Safely consumed gadung tuber chips were obtained from fermentation of the chips for 120 hours from which cyanides content as low as $49.41 \mathrm{mg} / \mathrm{kg}$ was achieved. The logistic equation successfully described the growth rate of Mucor racemosus under studied condition. The specific growth rate of Mucor racemosus in gadung chips was found to be $0.0297 / \mathrm{hr}$ or about a half of specific growth rate of that mold when grown in the readily consumed yeast-pepton-glucose (YPG) media.
\end{abstract}

Keywords: fermentation; yam; monod; Mucor racemosus; cyanogen

\begin{abstract}
Abstrak
Umbi gadung (Dioscorea hispida Dennst.) merupakan salah satu sumber karbohidrat yang digunakan sebagai makanan pokok yang biasa ditemukan di lahan kering di wilayah Indonesia. Namun, umbi ini kurang dimanfaatkan karena adanya senyawa antinutrisi, yaitu cyanogenic glucosides. Penghilangan senyawa sianida dari bahan makanan dapat dilakukan baik dengan metode fisik, kimia atau biologi. Penelitian ini bertujuan untuk mengkaji pengaruh waktu pada detoksifikasi irisan umbi gadung dari senyawa sianida melalui fermentasi dengan menggunakan kapang Mucor racemosus dan kinetikanya. Cuplikan irisan umbi gadung diambil dari sistem fermentasi pada setiap jeda waktu 24 jam untuk dianalisis kadar biomassa dan sianidanya. Hasil penelitian menunjukkan bahwa kandungan sianida menurun seiring dengan bertambahnya waktu fermentasi. Irisan umbi gadung yang aman dikonsumsi dapat diperoleh dari fermentasi irisan ubi gadung selama 120 jam dengan kandungan sianida serendah 49,41 mg/kg. Persamaan logistik berhasil menggambarkan tingkat pertumbuhan kapang Mucor racemosus dengan baik. Tingkat pertumbuhan spesifik dari Mucor racemosus pada irisan
\end{abstract}


umbi gadung adalah 0,0297/jam atau sekitar setengah dari laju pertumbuhan spesifik jamur tersebut saat dibudidayakan pada media yang siap dikonsumsi, seperti ragi-pepton-glukosa (YPG).

Kata kunci: fermentasi; gadung; monod; Mucor racemosus; sianogen

How to Cite This Article: Widiyanti, M. dan Kumoro, A.C., (2017), Kinetika Detoksifikasi Umbi Gadung (Dioscorea hispida dennst.) Secara Fermentasi dengan Kapang Mucor racemosu, Reaktor, 17(2), 81-88, http://dx.doi.org/10.14710/reaktor.17.2.81-88

\section{PENDAHULUAN}

Umbi gadung (Discorea hispida dennst.) merupakan sumber pangan kaya karbohidrat yang mudah dijumpai di wilayah Indonesia pada musim kemarau. Namun, adanya senyawa antinutrisi seperti dioskorin, histamin, saponin, dan glukosida sianogenik yang terkandung di dalamnya menyebabkan bahan pangan ini kurang diminati masyarakat. Glukosa dalam glikosida sianogenik dapat mengalami hidrolisis dengan katalis enzim atau asam, sehingga asam sianida $(\mathrm{HCN})$ dapat terlepas dari senyawa kompleks tersebut (Sasongko, 2009). Bhatia dkk. (2002) menjelaskan bahwa proses hidrolisis glukosida sianogenik dengan bantuan enzim $\beta$-glukosidase terjadi pada ikatan $\beta$ 1,4-glukosida, yaitu alkil- dan aril $\beta$-D- glukosidanya menghasilkan disakarida, oligosakarida dan hidroksinitril. Selanjutnya, hidroksinitril terurai secara enzimatis menjadi sianida dan campuran karbonil. Takó dkk. (2010) menyatakan bahwa $\mathrm{pH}$ optimum untuk golongan enzim glukosidase berkisar antara 4-6. Oleh karena itu, glukosida sianogenik dapat terhidrolisis dan terurai menghasilkan HCN dalam sistem pencernaan yang bersuasana asam pada manusia dan hewan sehingga dapat menyebabkan keracunan. Damardjati dkk. (1993) mengelompokan kadar sianida dalam makanan menjadi empat golongan, yaitu tidak beracun $(<50 \mathrm{mg} / \mathrm{kg})$, agak beracun $(50-80 \mathrm{mg} / \mathrm{kg})$, beracun $(80-100 \mathrm{mg} / \mathrm{kg})$ dan sangat beracun $(>100$ $\mathrm{mg} / \mathrm{kg}$ ). Dengan kandungan sianida hingga mencapai $425,44 \mathrm{mg} / \mathrm{kg}$ (Sasongko, 2009), maka umbi gadung tergolong sangat beracun dan tidak aman jika langsung dikonsumsi. Oleh karena itu, perlu dilakukan upaya untuk mengolah umbi gadung dengan menurunkan kandungan sianidanya hingga mancapai ambang batas yang aman untuk dikonsumsi.

Penghilangan senyawa sianida dari bahan makanan dapat dilakukan baik dengan metode fisik, kimia atau biologi. Masyarakat Indonesia telah sejak lama menerapkan metode penghilangan sianida dalam umbi gadung, seperti perendaman dalam larutan garam dapur, perendaman dalam air mengalir, pemberian abu gosok, pengepresan maupun dengan perlakuan panas (penjemuran dan perebusan umbi) (Sunarsih dkk., 2007). Di Malaysia, umbi gadung didetoksifikasi secara tradisional dengan perebusan, pemanggangan atau perendaman dalam air yang mengalir selama 7 hari (Hudzari dkk., 2011). Sedangkan rakyat Thailand menghilangkan sianida dalam umbi gadung dengan pengupasan kulit, pengirisan, perendaman dalam air yang mengalir selama 7 hari, atau perendaman dalam air garam yang diganti setiap hari selama 5 hari dan dilanjutkan dengan penjemuran. Selanjutnya, irisan umbi gadung kering dapat direbus atau dikukus sebelum dikonsumsi (Tatiyakul dkk., 2012).

Namun, metode perendaman perlu dilakukan secara berulang selama sekitar 3-5 hari sehingga kurang efisien (Harijono dkk, 2008). Selain itu, hingga saat ini belum ada prosedur yang baku untuk mengolah umbi gadung hingga layak dikonsumsi. Kordylas (1991) melaporkan bahwa pencucian atau perendaman dapat menurunkan kadar sianida dalam bahan pangan. Hardjo (2005), menunjukkan bahwa dengan perendaman irisan umbi di dalam larutan garam 7,5\% selama 72 jam dapat menurunkan kadar $\mathrm{HCN}$ dari 100,69 mg/kg menjadi $18,75 \mathrm{mg} / \mathrm{kg}$. Harijono dkk. (2008) menggunakan teknik pemanasan terbatas untuk menurunkan kadar sianida dalam umbi gadung. Pemanasan irisan umbi gadung setebal \pm 5 mm dalam kantung plastik tertutup pada suhu $50^{\circ} \mathrm{C}$ selama 12 jam mampu menurunkan kadar sianida dari $469,50 \mathrm{mg} / \mathrm{kg}$ menjadi $53,43 \mathrm{mg} / \mathrm{kg}$. Kumoro dkk. (2011) menurunkan kadar sianida dalam irisan umbi gadung dengan proses perendaman dalam air yang mengalir. Melalui proses tersebut, kadar sianida dalam irisan umbi gadung turun hingga hingga 50,55\% dari kadar awalnya setelah tumpukan irisan umbi gadung dialiri air dengan laju volumetric 3L/menit selama 3 jam. Akan tetapi proses ini menghasilkan air limbah yang mengandung sianida dalam jumlah yang banyak sehingga tidak efisien diterapkan dalam skala industri.

Selain dilakukan secara fisika dan kimia, penghilangan kandungan sianida dalam bahan pangan juga dapat secara biologi. Pada proses pengolahan singkong, baik melalui proses perendaman maupun fermentasi seperti pada pembuatan iafun, gari dan ogi, hidrolisis senyawa glukosida sianogen dibantu oleh enzim hidrolase ekstraseluler mikroba (Ketiku dkk., 1978). Salah satu mikroba yang terlibat adalah Mucor sp. Suliantari dan Rahayu (1990) melaporkan penurunan kadar sianida dalam umbi gadung dan kacang-kacangan selama fermentasi. Sasongko (2009) melakukan detoksifikasi irisan umbi gadung menggunakan kapang Mucor sp. yang diisolasi dari ragi tape merk Gedang dan berhasil menurunkan kadar sianida dari $425,44 \mathrm{mg} / \mathrm{kg}$ menjadi $146,04 \mathrm{mg} / \mathrm{kg}$ setelah fermentasi berlangsung selama 72 jam menggunakan inokulum $15 \%(\mathrm{v} / \mathrm{b})$. Kumoro dkk. (2016) berhasil menurunkan kadar sianida dalam 450 g irisan umbi gadung dari 390,96 menjadi 48,12 $\mathrm{mg} / \mathrm{kg}$ melalui fermentasi menggunakan 5 ragi tapai selama 7 hari. Namun, semua penelitian tersebut tidak meninjau kinetika pertumbuhan mikroba (kapang, 
bakteri dan ragi) karena lebih menitikberatkan pada upaya penurunan kadar sianida alam irisan umbi gadung saja.

Keberhasilan proses fermentasi dipengaruhi oleh beberapa faktor, diantaranya jenis dan kondisi bahan baku, jenis dan jumlah mikroba, serta waktu proses fermentasi. Oleh karena itu, pada penelitian ini dipelajari pengaruh waktu fermentasi terhadap penurunan kadar sianida dalam irisan umbi gadung dan kinetika pertumbuhan kapang Mucor racemosus.

\section{BAHAN DAN METODE}

Bahan

Bahan baku dalam penelitian ini menggunakan umbi gadung siap panen yang berumur \pm 9 bulan yang diperoleh dari kebun rakyat di daerah Gunung Pati, Semarang, Jawa Tengah. Kapang Mucor racemosus dibeli dari Laboratorium Mikrobiologi, Program studi Teknik Kimia, Institut Teknologi Bandung. Akuades diperoleh dari Reverse Osmosis Unit yang tersedia di Departemen Teknik Kimia, Fakultas Teknik, Universitas Diponegoro. Sementara itu, semua reagen kimia dengan kualitas analisis $(\geq 99,90 \% \mathrm{~b} / \mathrm{b})$,seperti $\mathrm{AgNO}_{3}, \mathrm{NaOH}, \mathrm{NH}_{4} \mathrm{OH}, \mathrm{KI}$ dan $\mathrm{HCl}$, potato-dextrose agar (PDA) instan dan PDB dibeli dari distributor resmi bahan kimia di kota Semarang.

\section{Metode}

Fermentasi irisan umbi gadung menggunakan kapang Mucor racemosus dilakukan dengan pengirisan umbi gadung, menjadi kepingan setebal \pm 5 mm dengan luas $5 \mathrm{~cm} \times 5 \mathrm{~cm}$. Kemudian, irisan umbi gadung tersebut di cuci bersih dan ditiriskan. Selanjutnya, $450 \mathrm{~g}$ irisan umbi gadung tersebut difermentasi dalam labu Erlenmeyer yang diletakkan pada pengguncang (shaker) elektrik untuk menjaga keseragaman pencampuran. Fermentasi dilakukan pada suhu kamar dan intensitas paparan cahaya yang tetap dengan penambahan kapang Mucor racemosus

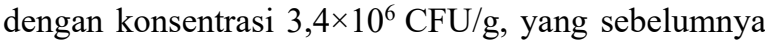
telah ditumbuhkan dalam media agar PDA selama 5-7 hari (Jakovljevic dkk., 2014). Sampel irisan umbi gadung diambil dari system fermentasi pada waktu 24, 48, 72, 96, 120, 144, dan 168 jam. Pada sebagian sampel, sejumlah miselium diambil dengan pencucian sampel dengan air nirmineral yang steril dan disaring pada kertas saring Whatman No.1. Kertas saring dan miselium dikeringkan pada suhu $80^{\circ} \mathrm{C}$ dianalisis massa kapangnya tanpa perlakuan lebih lanjut secara gravimetri (Jakovljevic dkk., 2014). Sebagian sampel dicuci dengan air suling hingga bebas kapang dan dikeringkan dalam oven listrik pada suhu $\pm 60^{\circ} \mathrm{C}$ selama 8 jam. Irisan umbi gadung kering kemudian digiling dengan blender dan diayak dengan ayakan 80 mesh (British Standard). Analisis kadar sianida dilakukan menggunakan metode titrasi alkali seperti yang disarankan oleh AOAC (1990). Percobaan dilakukan hingga kadar sianida di dalam irisan umbi gadung konstan. Untuk memastikan keakuratan data, percobaan dilakukan secara duplo, dan hasil pengukurannya dilaporkan sebagai rerata.

Kinetika pertumbuhan kapang Mucor racemosus diperkirakan mengikuti persamaan eksponensial yang ditunjukkan oleh persamaan (1) (Mitchell dkk., 2004).

$$
\frac{d X}{d t}=\mu . X
$$

Laju pertumbuhan spesifik kapang Mucor racemosus diperkirakan denagn menganggap hanya merupakan fungsi jumlah biomassa yang berupa persamaan logistic menurut persamaan (2) (Spier dkk., 2009):

$$
\mu=\mu_{\max } \cdot\left(1-\frac{x}{X_{\max }}\right)
$$

$X$ adalah konsentrasi kapang Mucor racemosussetiap saat $(\mathrm{g} / \mathrm{g}), X_{0}$ adalah konsentrasi awal kapang Mucor racemosus $(\mathrm{g} / \mathrm{g}), X_{\max }$, adalah konsentrasi maksimum kapang Mucor racemosus $(\mathrm{g} / \mathrm{g}), \quad t$ adalah waktu fermentasi (jam), $\mu$ adalah laju pertumbuhan spesifik $\left(\mathrm{jam}^{-1}\right)$ dan $\mu_{\max }$ adalah laju pertumbuhan spesifik maksimum $\left(\mathrm{jam}^{-1}\right)$. Jika spora yang ditanam dalam keadaan tidak aktif (dormant), maka akan dijumpai fase penyesuaian (lag phase) sebelum massa kapang meningkat. Laju penggunaan substrat oleh kapang Mucor racemosus diperkirakan dengan mempertimbangkan penggunaan substrat untuk menjaga biomassa kapang dan untuk menguraikan substrat glikosida sianogenik menjadi asam sianida. Laju penggunaan substrat dinyatakan dengan persamaan (3) (Aynseley dkk., 1990; Balmant dkk., 2015):

$$
\frac{d S}{d t}=-\frac{1}{Y_{x / s}} \frac{d X}{d t}-m \cdot X
$$

dengan $Y_{x / s}$ adalah yield substrat menjadi biomassa $(\mathrm{g} / \mathrm{g})$, sedangkan $m$ adalah tetapan penggunaan substrat untuk menjaga biomassa kapang $\left(\mathrm{jam}^{-1}\right)$.

\section{HASIL DAN PEMBAHASAN \\ Karakteristik Bahan Baku}

Berdasarkan analisis proksimat yang telah dilakukan, kandungan komponen makro pada umbi gadung disajikan pada Tabel 1 .

Tabel 1. Kandungan nutrisi umbi gadung

\begin{tabular}{lcc}
\hline Komponen & $\begin{array}{c}\text { Umbi gadung } \\
\text { segar }^{(a)}\end{array}$ & $\begin{array}{c}\text { Tepung umbi gadung } \\
\text { terfermentasi Mucor } \\
\text { racemosus }^{(b)}\end{array}$ \\
\hline Karbohidrat & $18 \%$ & $91,51 \%$ \\
Protein & $1,81 \%$ & $6,93 \%$ \\
Lemak & $1,6 \%$ & $0,39 \%$ \\
Abu & $0,7 \%$ & $1,17 \%$ \\
Air & $77 \%$ & $15,54 \%$ \\
HCN & $409,05 \mathrm{mg} / \mathrm{kg}^{(\mathbf{b})}$ & $21,33 \mathrm{mg} / \mathrm{kg}$ \\
\hline
\end{tabular}

a) Setyowati dan Siagian (2004), ${ }^{\text {b) Penelitian ini }}$

Seperti terlihat pada Tabel 1, kandungan karbohidrat pada tepung gadung cukup tinggi, yaitu mencapai 91,51 g/100 g bahan. Pengolahan umbi gadung segar menjadi tepung gadung dapat mengurangi kadar air dari $77 \%$ menjadi $15,54 \%$. Dengan demikian, menyimpan gadung dalam bentuk 
tepung lebih tahan dari serangan jamur dan aktivitas mikroflora lainnya sehingga memiliki daya simpan yang lebih lama (Kumoro dkk., 2016).

Walaupun umbi gadung mempunyai potensi yang besar untuk dijadikan sebagai bahan pangan, namun pemanfaatannya masih sangat terbatas karena adanya zat antinutrisi yang berupa glukosida sianogenik yang dapat berdampak negatif pada kesehatan. Umbi gadung segar yang digunakan dalam penelitian ini memiliki kadar sianida sebesar 409,05 $\mathrm{mg} / \mathrm{kg}$. Kadar sianida ini masih sangat tinggi dan dapat membahayakan kesehatan apabila umbi gadung tersebut langsung dikonsumsi. Ambang batas kadar $\mathrm{HCN}$ dalam bahan pangan menurut FAO yaitu $<50$ $\mathrm{mg} / \mathrm{kg}$ (Sasongko, 2009). Pada penelitian ini, proses fermentasi dikondisikan sebagai proses penghilangan/ pengurangan kadar sianida menggunakan kapang Mucor racemosus dengan konsentrasi 3,4 ×106 CFU/g yang dilakukan pada berbagai waktu fermentasi.

Selain kandungan karbohidratnya yang tinggi, umbi gadung juga mengandung $1,2 \mathrm{mg} / \mathrm{g}$ senyawa bioaktif dioscoran (Webster dkk., 1984; Hikino dkk., 1986), yang merupakan protein yang berfungsi sebagai antioksidan (Shewry, 2003), antihipertensi (Myoda dkk., 2006), dan untuk menanggulangi penyakit diabetes melitus (Sunarsih dkk., 2007). Umbi gadung juga mengandung BioCalcium $(132,4 \mathrm{mg} / \mathrm{kg})$ dan BioPhosphor (2398 $\mathrm{mg} / \mathrm{kg})$ yang merupakan bahan aktif untuk mengatasi berbagai penyakit yang berkaitan kekurangan mineral pada tulang (Chen dan Voregen, 2004).

\section{Profil Penurunan Kadar Sianida dalam Irisan Umbi Gadung}

Profil perubahan kadar sianida dalam irisan umbi gadung pada berbagai waktu fermentasi disajikan pada Gambar 1. Sebagai perbandingan, sebuah percobaan fermentasi alamiah (tanpa penambahan kapang Mucor racemosus) terhadap irisan umbi gadung juga dilakukan.

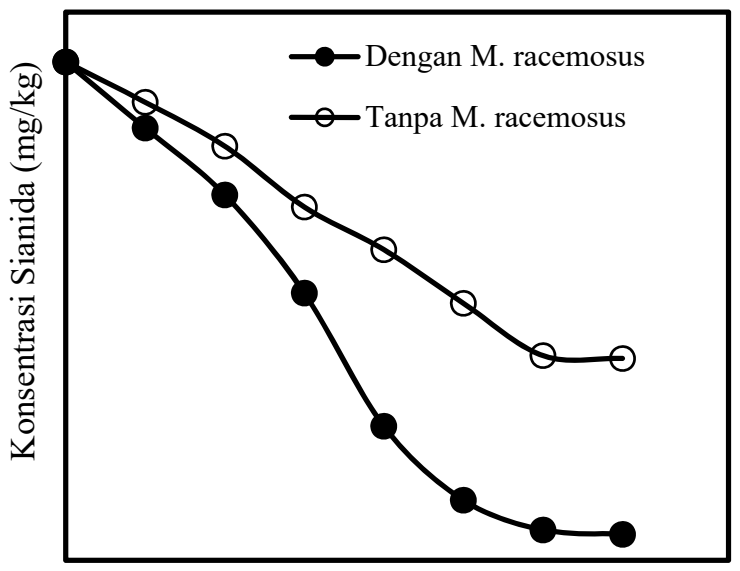

Waktu (jam)

Gambar 1. Profil kadar sianida dalam irisan umbi gadung pada berbagai waktu fermentasi
Gambar 1 menunjukkan bahwa fermentasi irisan umbi gadung tanpa menggunakan kapang Mucor racemosus selama 168 jam hanya dapat mengurangi kandungan sianida dari 390,96 mg/kg hingga 170,88 mg/kg (Kumoro dkk., 2016 ). Dalam hal ini, ada dua kemungkinan yang dapat terjadi, yaitu adanya mikroflora asing yang bisa menyebabkan fermentasi pada umbi gadung atau hidrolisis autolitik glikosida sianogenik mungkin terjadi bersamaan dengan pelarutan $\mathrm{HCN}$ dalam media fermentasi (Ketiku dkk., 1978). Akan tetapi, meskipun mikroorganisme-mikroorganisme asing dalam fermentasi irisan umbi gadung memiliki kemampuan untuk menghidrolisis glikosida sianogenik, namun perannya dalam proses detoksifikasi selama fermentasi sangat rendah (Wetsby dan Twiddy, 1992).

Pada Gambar 1 juga dapat dilihat bahwa fermentasi irisan umbi gadung menggunakan kapang Mucor racemosus mampu menurunkan kadar sianida dalam irisan umbi gadung dari 409,05 mg/kg hingga $21,33 \mathrm{mg} / \mathrm{kg}$. Pada gambar tersebut juga terlihat dengan jelas bahwa waktu fermentasi sangat berpengaruh terhadap penurunan kadar sianida dalam irisan umbi gadung. Semakin lama proses fermentasi yang dilakukan, maka semakin rendah kadar sianida yang tersisa dalam umbi gadung. Hal ini dikarenakan semakin lama waktu fermentasi, maka semakin banyak jumlah kapang Mucor racemosusyang tumbuh dan memproduksi enzim yang dapat menghidrolisis senyawa sianida untuk membebaskan HCN (Sasongko, 2009). Mucor racemosus merupakan salah satu jenis kapang penghasil enzim protease dengan aktivitas proteolitik yang tinggi (Alves dkk., 2005). Selain itu, selama pertumbuhannya Mucor racemosus juga menghasilkan enzim-enzim yang lain, seperti $\beta$ glukosidase, invertase, alkaline fosfat, fitase dan lipase yang juga dapat berperan dalam proses detoksifikasi (Jakovljevic dkk., 2014; Araujo dkk., 2016).

Apabila dibandingkan dengan kadar sianida pada umbi gadung sebelum difermentasi $(409,05$ $\mathrm{mg} / \mathrm{kg}$ ), maka setelah fermentasi selama 120 jam terjadi penurunan kadar sianida yang cukup besar yaitu $87,84 \%$ menjadi sebesar $49,41 \mathrm{mg} / \mathrm{kg}$. Dengan kadar sianida tersebut, maka irisan umbi gadung hasil fermentasi selama 120 jam ini sudah memenuhi ambang batas kadar HCN dalam bahan pangan menurut FAO yaitu $<50 \mathrm{mg} / \mathrm{kg}$ (Sasongko, 2009). Dosis kadar HCN dalam bahan pangan yang dapat mematikan manusia sekitar 0,5 hingga $3,5 \mathrm{mg} / \mathrm{kg}$ berat badan (Bradbury, 1991). Hasil ini lebih baik daripada fermentasi irisan umbi gadung menggunakan ragi tapai dengan inokulasi $5 \mathrm{~g} / 450 \mathrm{~g}$ irisan umbi gadung selama 120 jam yang hanya mampu menurunkan kadar sianida dari 390,96 mg/kg menjadi $64 \mathrm{mg} / \mathrm{kg}$ (Kumoro dkk., 2016). Akan tetapi, fermentasi yang terlalu lama (lebih dari 120 jam) menyebabkan irisan umbi gadung menjadi lunak karena adanya degradasi dinding sel umbi gadung oleh aktivitas enzim pektinase dan selulase (Okolie dan Ugochukwu, 1988). 


\section{Profil Laju Penurunan Kadar Sianida dalam Irisan Umbi Gadung}

Profil laju penurunan kadar sianida dalam irisan umbi gadung dapat dilihat pada Gambar 2. Kecepatan penurunan kadar sianida dalam irisan umbi gadung yang difermentasi dengan kapang Mucor racemosusterus meningkat dan puncaknya terjadi pada waktu 96 jam. Hal ini terjadi karena pada awal proses fermentasi persediaan substrat masih dalam jumlah yang berlebih. Sebagai spesies dari genus kapang dimorfik, Mucor racemosus memerlukan karbon dioksid dan gula heksosa untuk membentuk kuncup multipolar seperti pada ragi atau hifa yang bercabang (Borgia dan Sypherd, 1977; L"ubbeh"usen dkk., 2004; Bredenkamp dkk., 2010).

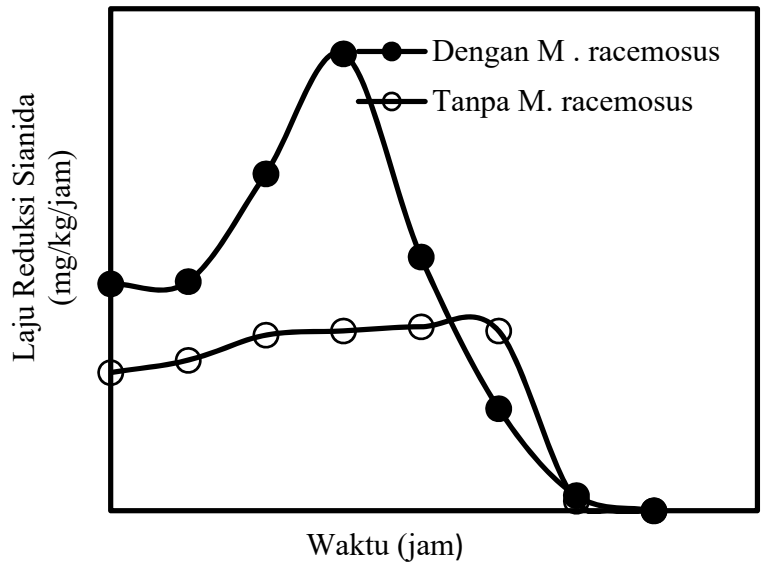

Gambar 2. Profil laju penurunan kadar sianida dalam irisan umbi gadung pada berbagai waktu fermentasi

Setelah 96 jam, laju penurunan kadar sianida justru mengalami perlambatan hingga akhirnya berhenti pada 168 jam. Hal ini terjadi karena substrat (termasuk glukosida sianogenik) yang dibutuhkan oleh kapang untuk tumbuh dan diuraikan menjadi asam sianida sudah sangat sedikit jumlahnya. Selama masa pertumbuhan, Mucor racemosus menghasilkan enzim $\beta$-glukosidase, protease dan lipase yang digunakan untuk menghidrolisis glukosida sianogenikdan membebaskan HCN (Araujo dkk., 2016).

Pada fermentasi irisan umbi gadung tanpa Mucor racemosus, laju penurunan kadar sianida terus meningkat hingga 120 jam. Setelah itu, nyaris tidak ada lagi penurunan kadar sianida dalam irisan umbi gadung.

\section{Profil Massa Kapang Mucor Racemosus dalam Irisan Umbi Gadung}

Pertumbuhan massa kapang Mucor racemosus dalam irisan umbi gadung selama proses fermentasi ditampilkan pada Gambar 3. Secara umum, pertumbuhan kapang dimulai dengan pembentukan tunas dari spora kapang yang diinokulasi dan kemudian segera diikuti dengan pembesaran hifa (Dantigny dkk., 2002). Semakin lama proses fermentasi dijalankan, maka semakin banyak jumlah kapang yang tumbuh pada irisan umbi gadung yang ditandai dengan peningkatan massanya. Sesuai dengan teori, massa kapang kering terus meningkat secara eksponensial mono fase sejak inokulasi hingga 168 jam. Fenomena yang serupa juga ditemukan oleh Jakovljevic dkk. (2014) pada pertumbuhan kapang Mucor racemosus Fresenius. Jakovljevic dkk. (2014) menambahkan bahwa fase stasioner untuk kapang Mucor racemosus baru dimulai pada waktu 216 jam dan berakhir pada 288 jam, selanjutnya kapang mengalasi otolisis dan menyebabkan massa kapang berkurang.

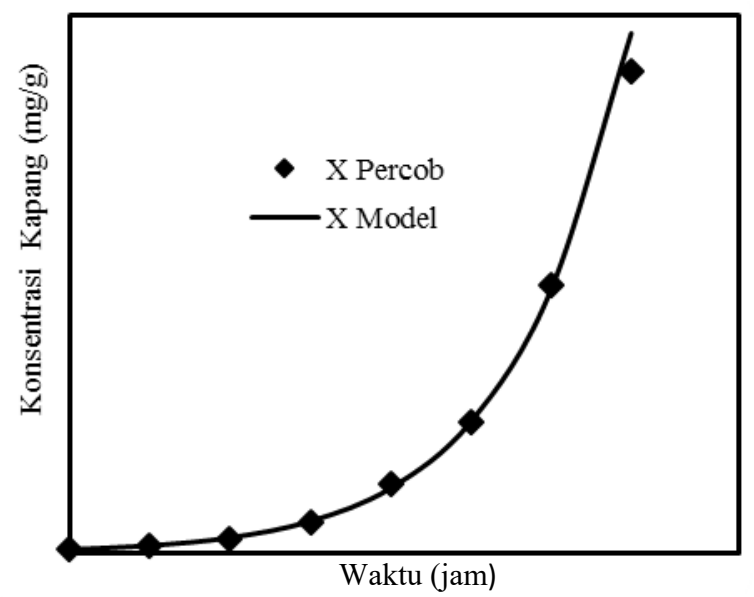

Gambar 3. Profil massa kapang Mucor racemosus selama proses fermentasi

Pada Gambar 3 dapat dilihat bahwa model persamaan logistic yang disarankan oleh (Mitchell dkk., 2004) dapat menggambarkan profil pertumbuhan Mucor racemosus dengan sangat baik. Hampir semua data percobaan berhimpit dengan kurva yang mewakili hasil perhitungan konsentrasi kapang pada setiap waktu fermentasi.

\section{Profil Massa Substrat pada Irisan Umbi Gadung}

Dalam penelitian ini, dianggap bahwa karbon total merupakan substrat yang digunakan oleh Mucor racemosus untuk tumbuh, berkembang dan menghasilkan enzim yang berperan dalam hidrolisis glukosida sianogenik menjadi HCN. Oleh karena itu, perubahan massa substrat diwakili oleh perubahan karbohidrat, protein, lemak dan serat dalam irisan umbi gadung. Profil perubahan konsentrasi substrat pada berbagai waktu fermentasi ditampilkan dalam Gambar 4.

Gambar 4 menunjukkan bahwa model persamaan matematika yang melibatkan penggunaan substrat untuk pertumbuhan dan pemeliharaan kapang yang disarankan oleh (Aynseley dkk., 1990) dapat menggambarkan profil perubahan substrat dengan cukup baik. Walaupun kurva yang mewakili hasil perhitungan konsentrasi kapang pada setiap waktu fermentasi mempunyai pola yang sama dengan data percobaan, namun pada umumnya nilainya lebih tinggi daripada data percobaan. 


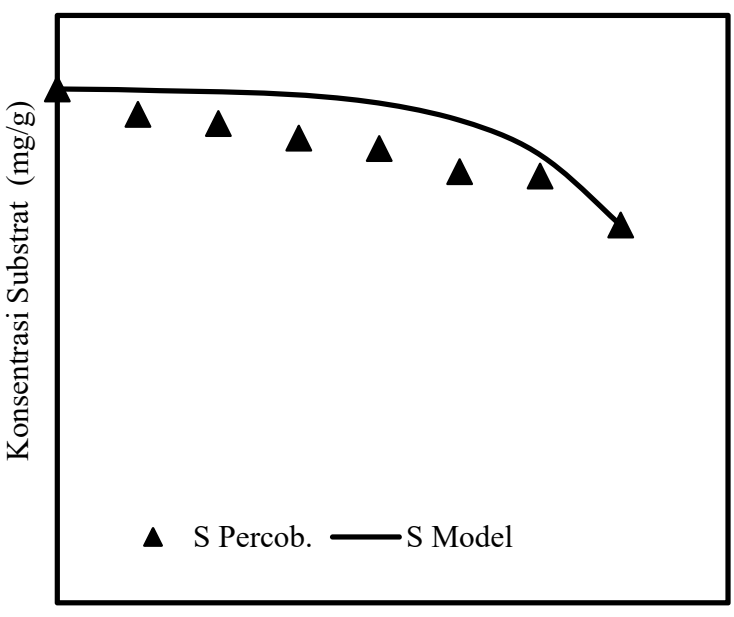

Waktu (jam)

Gambar 4. Profil perubahan konsentrasi substrat pada berbagai waktu fermentasi

\section{Data Parameter Kinetika Fermentasi Irisan Umbi Gadung dengan Kapang Mucor racemosus \\ Optimasi terhadap parameter-parameter}

kinetika yang terdapat pada persamaan (1), (2), dan (3) menghasilkan laju pertumbuhan spesifik maksimum Mucor racemosus pada media irisan umbi gadung mencapai 0,0297/jam. Sedangkan penelitian terdahulu yang pernah dilakukan oleh Orlowski (1981), pada media yeast-pepton-glucose (YPG) mempunyai laju pertumbuhan spesifik antara 0,043 hingga 0,430/jam. Dantigny dkk. (2002) melaporkan bahwa laju pertumbuhan miselium Mucor racemosus sebesar 0,5454/jam. Sedangkan Mucor circinelloides ATCC 1216b yang dibudidayakan secara anerobik pada media glukosa mempunyai laju pertumbuhan spesifik maksimum sebesar 0,05 $\pm 0,03 /$ jam (Bredenkamp dkk., 2010). Laju pertumbuhan spesifik Mucor racemosus yang diperoleh pada penelitian ini lebih rendah karena media fermentasi yang digunakan yaitu irisan gadung mempunyai molekul substrat lebih kompleks dibandingkan dengan YPG dan PDA yang mempunyai molekul substrat yang lebih sederhana. Konsentrasi kapang maksimum $\left(X_{\text {maks. }}\right), Y_{x / s}$ dan $m$ yang diperoleh pada penelitian ini adalah 11.475 $\mathrm{mg} / \mathrm{g}, 13,9323(\mathrm{~g} / \mathrm{g})$ dan 0,1143/jam.

Berdasarkan data-data parameter kinetika fermentasi irisan umbi gadung dengan kapang Mucor racemosus, maka dapat dirancang proses dan peralatan untuk menurunkan kadar sianida dalam umbi gadung dalam skala pilot plant maupun skala komersial.

\section{KESIMPULAN}

Proses penghilangan sianida dalam umbi gadung secara fermentasi menggunakan kapang Mucor racemosus berhasil dilakukan. Semakin lama waktu fermentasi, maka kadar sianida dalam irisan umbi gadung juga semakin rendah. Fermentasi irisan umbi gadung menggunakan $3,4 \times 10^{6} \mathrm{CFU} / \mathrm{g}$ innokulum kapang Mucor racemosusselama 5 hari berhasil merupakan kondisi yang cukup baik untuk memperoleh irisan umbi gadung yang aman dikonsumsi dengan kadar sianida 49,41 mg/kg. Laju pertumbuhan spesifik Mucor racemosus pada media irisan umbi gadung adalah 0,0297/jam dengan konsentrasi kapang maksimum $\left(X_{\text {maks. }}\right), Y_{x / s}$ dan $m$ sebesar $11.475 \mathrm{mg} / \mathrm{g}, 13,9323$ (g/g) dan 0,1143/jam.

\section{DAFTAR PUSTAKA}

Alves, M.H., Galba, M., and Kaoru, O., (2005), Detection of Extracellular Protease in Mucor Species, Revista Iberoamericana de Micologia, 22, pp.114117

AOAC, 1990, Official Methods of Analysis, 15 ${ }^{\text {th }}$, Washington, D.C.

Araujo, T.R., Petkowicz, C.L.O., Cardoso, V.L., Filho, U.C., and Vieira, P.A., (2016), Biopolymer Production Using Fungus Mucor racemosus Fresenius and Glycerol as Substrate, Polimeros, 26(2), pp. 144151.

Aynseley, M., Ward, A.C., and Wright, A.R., (1990), A Mathematical Model for the Growth of Mycelial Fungi in Submerged Culture, Biotechnology and Bioengineering, 35, pp. 820-830.

Balmant, W., Sugai-Guérios, M.H., Coradin, J.H., Krieger, N., Junior, A.F., and Mitchell, D.A., (2015), A Model for Growth of a Single Fungal Hypha Based on Well-Mixed Tanks in Series: Simulation of Nutrient and Vesicle Transport in Aerial Reproductive Hyphae, Plos One, DOI:10.1371/ journal.pone.0120307, pp. 1-22.

Bhatia, Y., Mishra, S., and Bisaria, V.S., (2002), Microbial $\beta$-glucosidases: Cloning, Properties, and Applications. Critical Reviews in Biotechnology, 22, pp. 375-407.

Bredenkamp, A., Velankar, H., van Zyl, W.H., and G*orgens, J.F., (2010), Effect of Dimorphic Regulation on Heterologous Glucose Oxidase Production by Mucor Circinelloides, Yeast, 27, pp. 849-860.

Borgia, P. and Sypherd, P.S., (1977), Control of $\beta$ glucosidase Synthesis in Mucor racemosus, Journal of Bacteriology, 130, pp. 812-817.

Bradbury, J.H., (1991), Properties and Analysis of Antinutritional Factors in Foods, ASEAN Food Journal, 6(4), pp.123-128.

Chen, Z.S. and Voregen, A.G.J.,(2004), Differently Sized Granules From Acetylated Potato and Sweet Potato Starches Differ in the Acetyl Substitution Pattern of their Amylase Populations, Carbohydrate Polymer, 56, pp. 219-226. 
Damardjati, D.S., Widowati, dan Suismono, (1993), Pembangunan Sistem Agroindustri Kassava, Balai Penelitian Pertanian, Sukamandi.

Dantigny, P., Mansur, C.S., Sautour, M., Tchobanov, I., and Bensoussan, M., (2002), Relationship Between Spore Germination Kinetics and Lag Time during Growth of Mucor racemosus, Letters in Applied Microbiology, 35, pp. 395-398.

Hardjo, M., (2005), Tepung Gadung (Dioscorea Hispida Dennst) Bebas Sianida dengan Merendam Parutan Umbi dalam Larutan Garam, Jurnal Matematika, Sains, dan Teknologi, 6(2), hal. 92-99.

Harijono, Sari, T.A., dan Martati, E., (2008), Detoksifikasi Umbi Gadung (Dioscorea hispida Dennst.) dengan Pemanasan Terbatas dalam Pengolahan Tepung Gadung, Jurnal Teknologi Pertanian, 9(2), hal. 75-82.

Hikino, H., Cono, C., Takahashi, M., Murakami, M., Kato, Y., Karikura, M. and Hayashi, T.,(1986), Isolation and Hypoglycemic Activity of Dioscorans A, B, C, D, E, and F; Glycans of Dioscorea Japonica Rhizophors, Planta Medica, 3, pp.168-171.

Hudzari, R.M., Ssomad, M.A.H.A., Rizuwan, Y.M., Asimi, M.N.N., Abdullah, A.B.C., and Fauzan, M.Z.M., (2011), Modification of Automatic Alkaloid Rem Oval System for Dioscorine, International Journal of Agronomy \& Plant Production, 2, pp.155161.

Jakovljević, V.D., Milićević, J.M., Stojanović, J.D., and Vrvić, M.M., (2014), The Ability of Fungus Mucor racemosus Fresenius to Degrade High Concentration of Detergent, Chemical Industry \& Chemical Engineering Quarterly, 20 (4), pp. 587-595.

Ketiku, A.O., Akinyele, I.O., Kenshiro, O., and Akinnowo, O., (1978), Changes in the Hydrocianic Acid Concentration during Traditional Processing of Cassava into Gari and Iafun, Food Chemistry, 3, pp. 221-228.

Kumoro, A.C., Retnowati, D.S.,and Budiyati, C.S., (2011), Removal of Cyanides From Gadung (Dioscorea Hispida Dennst.) Tuber Chips Using Leaching and Steaming Techniques, Journal of Applied Sciences Research, 7(12), pp. 2140-2146.

Kumoro, A.C., Ratnawati, R., Retnowati, D.S., and Budiyati, C.S., (2016), Microbial Detoxification of Gadung (Dioscorea Hispida Dennst) Tuber: Effect of Microbes Loading and Time, Proceeding of the $2^{\text {nd }}$ International Conference of Mathematics and Natural Sciences, Bandung. Paper No. LSC-307, pp. 1-6.

L"ubbeh"usen, T.L., Nielsen, J., and McIntyre, M., (2004), Aerobic and Anaerobic Ethanol Production by
Mucor Circinelloides during Submerged Growth, Applied Microbiology and Biotechnology, 63, pp. 543548.

Mitchell, D.A., von Meien, O.F., Krieger, N., and Dalsenter, F.D.H., (2004), A Review of Recent Developments in Modeling of Microbial Growth Kinetics and Intraparticle Phenomena in Solid-State Fermentation, Biochemical Engineering Journal, 17, pp. 15-26.

Myoda, T., (2006), Identification of Soluble Proteins and Interaction with Mannan in Mucilage of Dioscorea Opposita Thunb.(Chinese Yam Tuber), Food Science and Technology Research, 12(4), pp. 299-302.

Okolie, N.P. and Ugochukwu, E.N., (1988), Changes in Activities of Cell-Wall-Degrading Enzymes during Fermentation of Cassava (Manihot esculentu Crantz) with Citrobacter freundii, Journal of the Science of Food and Agriculture, 44, pp. 51-61.

Orlowski, M., (1981), Growth Rate Dependent Adjustment of Ribosom Function I the Fungus Mucor racemosus, Journal of Biochemistry, 196, pp.403-410.

Sasongko, P., (2009), Detoksifikasi Umbi Gadung (Dioscorea Hispida Dennst.) Proses Fermentasi Menggunakan Kapang Mucor racemosus, Jurnal Teknologi Pertanian, 10(3), hal. 205-215.

Setyowati, F.M. dan Siagian, (2004), Pemanfaatan Tumbuhan Pangan oleh Masyarakat Talang Mamak di Taman Nasional Bukit Tiga Puluh, Jambi, Biota Jurnal Ilmiah Ilmu-ilmu Hayati, IX(1), hal. 11-18.

Shewry, P.R., (2003), Tuber Storage Proteins, Annals of Botany, 91(7), pp. 755-769.

Spier, M.R., Letti, L.A.J., Woiciechowski, A.L., and Soccol, C.R., (2009), A Simplified Model for A. Niger FS3 Growth during Phytase Formation in Solid State Fermentation, Brazilian Archives in Biology and Technology, 52, pp. 151-158.

Suliantari dan Rahayu, P.W., (1990), Teknologi Fermentasi Biji dan Umbi-Umbian, PAU Pangan dan Gizi IPB, Bogor.

Sunarsih, E.S., Djatmika, and Utomo, R.S., (2007), Influence of Administration of Gadung Corm (Dioscorea hispida Dennst) Infusion to Decrease of Blood Glucose Level at Aloksan Inducted Male Diabetic Rats, Majalah Farmasi Indonesia, 18(1), pp. 29-33.

Takó, M., Farkas, E., Lung, S., Krisch, J., Vágvölgyi, C., and Papp, T., (2010), Identification of Acid- and Thermotolerant Extracellular $\beta$-glucosidase Activities in Zygomycetes Fungi, Acta Biologica Hungarica, 61, pp.101-110. 
Tatiyakul, J., Naksriarporn, T., and Pradipasena P., (2012), X-ray Diffraction Pattern and Functional Properties of Dioscorea hispida Dennst Starch Hydrothermally Modified at Different Temperatures, Food and Bioprocess Technology, 5, pp. 964-971.

Webster, J., Beck, W., and Ternai, B.,(1984), Toxicity and Bitterness in Australian Dioscorea bulbifera L. and Dioscorea hispida Dennst. from Thailand, Jornal Agriculture Food Chemistry, 32, pp.1087-1090.

Wetsby, A. and Twiddy, R., (1992), Characterization of Gari and Fu-fu Preparation Procedures in Nigeria, World Journal of Microbiology and Biotechnology, 8(2), pp.175-182. 